Published in final edited form as:

Cancer Epidemiol. 2014 April ; 38(2): 137-143. doi:10.1016/j.canep.2014.02.006.

\title{
Risk Factors for Kaposi's sarcoma among HIV-Positive Individuals in a Case Control Study in Cameroon
}

\author{
Kristen Stolka ${ }^{a}$, Paul Ndom ${ }^{b}$, Jennifer Hemingway-Foday ${ }^{a}$, Jeniffer Iriondo-Perez ${ }^{a}$, Wendell \\ Miley $^{c}$, Nazzarena Labo ${ }^{c, d}$, Stella; Jennifer ${ }^{e}$, Mahamat Abassora ${ }^{f}$, Godfrey Woelk ${ }^{f, g}$, Robin \\ Ryder $^{\text {h }}$, Denise Whitbyc, and Jennifer S Smith \\ aRTI International, 3040 Cornwallis Rd. Research Triangle Park, NC 27709 \\ bSOCHIMIO, Rue EMIA, après Gendarmerie Nationale, Box 25513, Yaoundé, Cameroon \\ cViral Oncology Section, AIDS and Cancer Virus Program, Frederick National Laboratory for \\ Cancer Research, BLDG 535, $4^{\text {th }}$ floor, Frederick, MD 21702 \\ dDepartment of Epidemiology, Johns Hopkins Bloomberg School of Public Health, 615 North \\ Wolfe Street, Baltimore, MD 21205 \\ eUniversity of California, 55 Laguna St., San Francisco, CA 94102 \\ 'Expanded Program on Immunization, BP 186, Garoua, Cameroon \\ gElizabeth Glaser Pediatric AIDS Foundation, 1140 Connecticut Avenue NW, Washington, DC \\ 20036 \\ hUniversity of California, 200 West Arbor Drive \#8485, San Diego, CA 92103 \\ i2103 McGavran-Greenberg, Department of Epidemiology, University of North Carolina at Chapel \\ Hill, Campus Box 7435, Chapel Hill, NC 27599
}

\section{Abstract \\ Background-Individuals co-infected with Kaposi's sarcoma herpesvirus (KSHV) and Human Immunodeficiency Virus (HIV) are at greatly increased risk of developing Kaposi's sarcoma (KS). The objective of the current analysis is to identify risk cofactors, for KS among HIV-positive individuals.}

Methods-We conducted a case-control study of KS in Cameroon on 161 HIV-positive and 14 HIV-negative cases and 680 HIV-positive and 322 HIV-negative controls. Participants answered a physician-administered questionnaire and provided blood and saliva specimens. Antibodies against KSHV lytic, K8.1, and latent, ORF73, antigens were measured by ELISA to determine

(C) 2014 Elsevier Inc. All rights reserved.

Corresponding Author Contact Information: Kristen Stolka, RTI International, 3040 East Cornwallis Rd., Research Triangle Park, NC 27709, Tel: +1-919-541-7403, Fax: +1-919-541-6416, kstolka@ rti.org.

Conflicts of Interest

None to declare.

Publisher's Disclaimer: This is a PDF file of an unedited manuscript that has been accepted for publication. As a service to our customers we are providing this early version of the manuscript. The manuscript will undergo copyediting, typesetting, and review of the resulting proof before it is published in its final citable form. Please note that during the production process errors may be discovered which could affect the content, and all legal disclaimers that apply to the journal pertain. 
KSHV serostatus. Conditional logistic regression was performed to determine multivariate odds ratios (OR) and 95\% confidence intervals (CI) for risk factors associated with KS among HIVpositive cases and controls.

Results-Overall, 98\% (158) of HIV-positive cases, 100\% (14) of HIV-negative cases, $81 \%$ (550) of HIV-positive controls, and 80\% (257) of HIV-negative controls were KSHV seropositive. Risk factors for KS among HIV-positive individuals included KSHV seropositivity (OR=9.6; 95\% CI 2.9, 31.5), non-use of a mosquito bed net (OR 1.9; 95\% CI 1.2, 2.9), minority ethnicity $(\mathrm{OR}=3.1 ; 95 \% \mathrm{CI} 1.1,9.3)$, treatment from a traditional healer ( $\mathrm{OR}=2.3$; $95 \% \mathrm{CI} 1.5,3.7)$, history of transfusion ( $\mathrm{OR}=2.4 ; 95 \%$ CI 1.5, 3.9), and family history of cancer $(\mathrm{OR}=1.9 ; 95 \%$ CI 1.1, 3.1).

Conclusion-KSHV seroprevalence of $\geq 80 \%$ indicates a high prevalence in the general population in Cameroon. Among HIV-positive individuals, the strong association of KS with nonuse of mosquito nets and treatment from traditional healers are compelling findings, consistent with recently reported data from East Africa.

\section{Keywords}

Kaposi's sarcoma (KS); Kaposi's sarcoma herpesvirus (KSHV); Human herpesvirus 8 (HHV-8); Human Immunodeficiency Virus (HIV); risk factors; Cameroon

\section{Introduction}

Kaposi's sarcoma (KS) is the most prevalent HIV and AIDS associated cancer worldwide [1-3]. Until the advent of the AIDS epidemic, KS was found in specific populations, notably individuals from equatorial Africa (endemic KS), older men from Eastern Europe and the Mediterranean (classic KS), and individuals who received an organ transplant or were immune-compromised (iatrogenic KS) [2].

Epidemic KS is considered the most common AIDS-associated malignancy [1,4], with an increased risk among HIV-positive individuals with lowered immune status [5,6]. Since the advent of combined anti-retroviral therapy (cART), the prevalence of epidemic KS has dramatically decreased in high income countries [5,7]. In Africa, however, KS continues to be one of the leading AIDS-defining illnesses, as well as one of the most prevalent cancers overall [3].

The etiologic agent that causes KS, human herpesvirus 8 (HHV-8), also known as Kaposi's sarcoma herpesvirus (KSHV), was discovered in 1994 [8]. The presence of KSHV alone, however, is not sufficient for the development of KS disease: a large proportion of individuals with KSHV never develop KS $[6,9,10]$. KSHV is transmitted chiefly via saliva [11-14], but the modes of transmission are likely different in different populations. In low KSHV prevalence areas, such as the US, KSHV mainly infects men who have sex with men (MSM), implicating risk factors related to sexual behavior [15]. In some regions of Africa, KSHV is very prevalent in the general population and increases with age beginning in childhood [16], suggesting that transmission is via non-sexual horizontal routes [14].

Cameroon is located within the "KS belt", the region along the equator in Africa that has the highest incidence of KS worldwide [17]. Endemic KS has been localized in areas of high 
altitude, cooler temperatures, and moderate rainfall [18], conditions found in the Northwest and Southwest regions of Cameroon. Countries in the KS belt generally have higher KSHV prevalence compared to elsewhere in Africa [17,19]. In areas outside of the KS belt, geographic pockets of high KSHV prevalence do not seem to systematically present with high KS rates [19].

Cameroon has been reported to have one of the highest prevalence of KSHV in the world (62\%) [20], as well as the highest prevalence of HIV in Western and Central Africa (5.3\%) [21]. While prevalence estimates of epidemic KS in Cameroon vary [20,22] KS is one of the most commonly diagnosed cancers among men and women and is estimated to comprise 15-20\% of all adult cancers [18]. The combination of the overall high prevalence of KSHV, geographic and environmental risk factors found in endemic KS regions, and the HIV epidemic in Cameroon, likely contribute to the high rates of KS [20,23,24].

To date, most prospective research on risk factors on AIDS-related KS has been conducted in East or Southern Africa. Little research of AIDS-related KS has been conducted in Central or West Africa, despite the intersection of known environmental and etiologic risk factors in this region. We report here results of a case-control study, including determination of KSHV seroprevalence and examination of risk factors for KS among HIV-positive individuals in Cameroon.

\section{Materials \& Methods}

In 2005, the National Institute of Allergy and Infectious Diseases (NIAID) funded the International Epidemiologic Databases to Evaluate AIDS (IeDEA) to identify epidemiological trends and answer evolving research questions associated with HIV using large cohort studies [25]. In 2006, the National Cancer Institute (NCI) provided additional funding to study HIV-associated cancers. Yaoundé, Cameroon served as the sentinel site for cancer research in IeDEA-Central Africa, through its collaboration with the Oncology Department of the General Hospital of Yaoundé and with Solidarité Chimiotherapie (SOCHIMIO), the largest non-governmental organization providing support to cancer patients in Cameroon.

\section{Study Design}

This prospective, matched case-control study nested within IeDEA-Central Africa, was conducted from 2009-2011, with the primary aim to identify risk factors for the development of KS among HIV-positive and HIV-negative individuals. Cases were identified amongst patients in the IeDEA cohort who presented with signs and symptoms of KS, through the SOCHIMIO cancer registry, and amongst referrals to the Oncology Department of the General Hospital of Yaoundé. Trained cancer specialists confirmed KS diagnosis through clinical examination, and, if necessary, a skin biopsy. HIV-positive and HIV-negative controls were identified by referring physicians through the HIV Care and Treatment Centers and Voluntary Testing and Counseling Centers at the General Hospital and the Military Hospital, both IeDEA sites in Yaoundé. To be eligible, all participants were required to be 21 years of age or older, to have resided in Cameroon for at least 6 months prior to enrollment, and to provide written informed consent. The study was designed so that 
four HIV-positive controls and two HIV-negative controls were matched to each KS case based on sex and 5-year age brackets. The protocol was reviewed and approved by the Cameroon National Ethics Committee and the Institutional Review Board (IRB) at RTI International.

\section{Data collection}

Physicians conducted a clinical examination and interview with each participant. A standardized questionnaire (see supplementary table 1) collected detailed information on potential risk factors for KS, including demographics, socio-economic status, environmental exposure, health-risk behaviors, reproductive health history, concurrent immunosuppressive conditions, and medical history. For HIV-positive cases and controls, information was also collected on suspected mode of HIV transmission and time since confirmed HIV infection. Additional clinical data on antiretroviral therapy (ART) was derived from a transfer form completed by the referring physician.

\section{Clinical specimens and KSHV diagnosis}

Whole blood, serum and saliva samples were collected from all participants at enrollment into the study. All specimen samples were shipped to the Viral Oncology Section at the Frederick National Laboratory for Cancer Research in Frederick, Maryland. Serum samples were tested for antibodies against two recombinant KSHV antigens, K8.1 and ORF73 using previously described ELISAs. ORF73 encodes LANA, which is expressed during latency and K8.1 encodes a glycoprotein that is expressed during lytic infection. ELISA methods, and relative interpretations, are described in [26].

\section{Statistical analysis}

Descriptive frequencies were obtained for key characteristics among cases and controls stratified by HIV status. Results of assays for K8.1 and ORF73 were analyzed separately and then combined: a subject was defined as seropositive for KSHV if they tested positive for K8.1 or ORF73.

Conditional logistic regression was used to obtain odds ratios (OR) and $95 \%$ confidence intervals (CI) for selected risk factors associated with KS status. Univariate analysis was conducted on KSHV serostatus and 22 questionnaire covariates. The initial multivariate model included variables with a significant unadjusted $\mathrm{OR}$ at $\alpha<.05$ and variables found to be associated with KS in the literature. HIV-related variables were excluded from the final model due to the limited data available. The final multivariate model was selected using a backwards stepwise algorithm. Data were analyzed using SAS v 9.2.

\section{Results}

\section{Description of the Study Population}

By the end of the enrollment period, we had accrued 175 cases, of which 161 (92\%) were HIV-positive (epidemic KS) and 14 (8\%) were HIV-negative (endemic KS), and 1002 controls, 680 (68\%) HIV-positive and 322 (32\%) HIV-negative (Table 1). As expected, HIV infection was strongly associated with $\mathrm{KS}$ risk (OR=5.45; 95\% CI: 3.10, 9.56; $\mathrm{p}<.0001)$. 
The prevalence of KSHV was 98\% (158/161) in HIV-positive cases, 100\% (14/14) in HIVnegative cases, $81 \%$ (550/680) in HIV-positive controls, and 80\% (257/322) in HIVnegative controls. Characteristics of all study participants are presented in detail in Table 1.

\section{Risk Factors for KS among HIV-positive Individuals}

Risk factors for KS were investigated in HIV-subjects. In the univariate analysis (Table 2), KS was associated with a positive test to any or either KSHV antigen, presence of electricity in the home, not sleeping under a mosquito net, and history of tobacco use $(\mathrm{p}<.05)$. KS was also associated with having four or more lifetime sexual partners, inconsistent condom use, history of a sexually transmitted infection (STI), treatment by a traditional healer, history of a transfusion, family history of cancer, WHO HIV clinical stage of III or IV at the start of antiretroviral therapy (ART), and duration of ART of less than 18 months ( $\mathrm{p}<.05)$. We analyzed variables found to be significant risk factors in other studies of KS, including the color of the soil where the participant spent time as a child, going barefoot as a child, and source of bathing water. However, none of these variables were shown to be significantly associated with $\mathrm{KS}$ in this analysis.

In the multivariate analysis (Table 3), KSHV seropositivity remained highly associated with KS disease (OR=9.6; 95\% CI 2.9, 31.5; $\mathrm{p}=.0002)$. Not sleeping under a mosquito net $(\mathrm{OR}=1.9 ; 95 \% \mathrm{CI} 1.2,2.9 ; \mathrm{p}=.006)$, receiving treatment from a traditional healer $(\mathrm{OR}=2.3$; $95 \%$ CI 1.5, 3.7; $\mathrm{p}=.0002)$, having a history of transfusion (OR=2.4; 95\% CI 1.5, 3.9; $\mathrm{p}=$. $0005)$, and a family history of cancer ( $\mathrm{OR}=1.9 ; 95 \% \mathrm{CI} 1.1,3.1 ; \mathrm{p}=.018)$ were positively associated with KS.

\section{Discussion}

Cameroon is a highly informative country in which to study the co-infection of HIV and KS because of the presence of environmental risk factors found in endemic KS areas and high rates of both KSHV and HIV. No study of KS of this magnitude has ever been performed in Cameroon or Central Africa, making this study the first of its kind. Our analysis revealed several important risk factors for KS among HIV-positive individuals, alongside KSHV seropositivity. In particular, use of a mosquito net and treatment from a traditional healer were of greatest interest due to possible relationships with risk factors previously described in the literature $[27,28]$.

The majority of study participants, HIV-positive and HIV-negative, were KSHV seropositive. The extremely high proportion of KSHV seropositivity in HIV-positive (81\%), and HIV-negative controls (80\%), indicate that KSHV infection is likely much more prevalent in the general population of Cameroon than previously understood.

A high proportion of participants from all groups (33\%-50\%) classified their work as professional, indicating a higher socio-economic status. Higher SES have been associated with both endemic, [29] and epidemic KS [30]. However, neither occupation nor education was associated with KS among HIV-positive individuals in our study. In contrast, participants without electricity in the home were moderately more likely to have KS $(\mathrm{OR}=1.9 ; 95 \%$ CI $0.9,4.5 ; \mathrm{p}=.1028)$ as did participants who did not sleep under a mosquito 
net (OR=1.9; 95\% CI 1.2, 2.9; $\mathrm{p}=.006)$. Although electricity in the home and use of a mosquito net can indicate higher income and education [31,32] higher SES was not associated with KS risk in our study, so use of a mosquito bed net represents some other protective effect. Plasmodium parasitemia has previously been shown to be a risk factor for KSHV infection [28], and a possible association between malaria and development of KS merits further investigation.

We found that participants whose ethnic group was not classified as Bantu or Semi-bantu were slightly more likely to have KS as compared to Semi-bantu (OR=3.1; 95\% CI 1.1, 9.3; $\mathrm{p}=.0702$ ). Region of origin was highly correlated with ethnic group (Figure 1), and therefore ethnicity may be a proxy for environmental exposure related to endemic KS risk.

Environmental cofactors reported in the literature include exposure to volcanic soils [18,33], going barefoot [29] and exposure to surface water [30]. The Semi-bantu typically originate from the cooler and drier western highlands (West and Northwest) and the Bantu from parts of the coastal South and Southwest regions characterized by long rainy seasons. Other ethnic groups typically live in the Northern regions, characterized by dry savanna (Extreme North) or volcanic mountains and plateaus (Adamawa and North).

Individuals located in areas of high rainfall may be more susceptible to KS due to greater exposure to surface water [34] or, potentially parasitic infections [28]. Although malaria is endemic throughout Cameroon, the coastal South and Southwest regions have the highest prevalence of malaria in the country [31,35]. Conversely, individuals in higher altitude regions in the North may be more susceptible to KS due to increased exposure to volcanic and iron-rich soils $[18,36]$. Although previous literature has shown an association between KS and playing outside barefoot as children, we only found a marginal association in our analysis ( $\mathrm{OR}=2.8 ; 95 \% \mathrm{CI} 0.8,10.4)$. This association may be related to exposure to soiltransmitted helminthes, e.g. hookworm, a common outcome of walking barefoot, which has been shown to be associated with an increased prevalence of KSHV [28]. Malaria and hookworm cause anemia, and thus tissue hypoxia, which is a known activator of KSHV replication, which could promote KS [37]. Moreover, systemic parasitic infections can cause profound immunological abnormalities that may alter cellular immune responses to KSHV, thus promoting KS [38,39].

On the other hand, the effect of ethnicity on the risk of KS development could be also due to genetic factors. We do observe an association between KS and self-reported family history of cancer ( $\mathrm{OR}=1.8,95 \% \mathrm{CI}, 1.2,2.7 ; \mathrm{p}=.0178)$. The role of host genetic factors in the risk of KS should be explored further.

We also found a significant association between KS and history of transfusion ( $\mathrm{OR}=1.9$, 95\% CI 1.3, 3.8; $\mathrm{p}=.0005)$, and ever receiving treatment from a traditional healer ( $\mathrm{OR}=2.4$, $95 \% \mathrm{CI}, 1.7,2.4 ; \mathrm{p}=.0002)$. Transfusion often occurs during hospitalization, which could have resulted from advanced HIV or undiagnosed KS. While the risk of KS among those who had transfusions should be explored further, the potential for unobserved confounding must be kept into account. The association of KS and traditional medicine could be related to the use of herbal products that when chewed or rubbed into the skin and mucosae may contribute to the transmission of KSHV through saliva and/or promote the development of 
KS through abrasive micro-trauma to the skin [40]. A recent study on natural products that promote KSHV reactivation found that 9 of the 28 most active plant extracts were from West Africa and 3 of those were specifically from Cameroon [27]. Additional investigation on traditional treatments may be warranted.

Heterosexual HIV exposure was moderately significantly associated with KS status (OR 1.9, 95\% CI, 1.3, 2.7; $\mathrm{p}=.0571$ ) as compared to other or unknown origin of exposure.

Heterosexual exposure is the most common modality of HIV transmission in Sub-Saharan Africa [41]. However, the absence of associations between KS and number of lifetime sexual partners or history of STIs reiterates the lack of evidence for sexual activity as a major route of KSHV transmission [42].

Finally, although the number of HIV-negative cases in this study (14) was not enough to provide statistically significant comparisons with the HIV-negative controls, they give us an interesting look into the potential differences between endemic and epidemic KS in Cameroon. Unlike the HIV-positive cases, the HIV-negative cases in our study were all male, of older ages, and mostly farmers. All of the HIV-negative cases tested positive to both KSHV antigens. This may be explained by an increase in the prevalence of seropositivity to KSHV antigens in older age, or could reflect an AIDS related deterioration of humoral immune responses in the HIV-positive cases.

\section{Conclusion}

This matched case-control study of KS among HIV-negative and HIV-positive participants in Cameroon is the first of its kind. The high prevalence of KSHV in both HIV-positive and HIV-negative participants indicates a notably higher prevalence of KSHV in the general population of Cameroon than previously understood. Multivariate risk factors for KS among HIV-positive participants included KSHV infection and cofactors, such as lack of mosquito bed net use, minority ethnicity, treatment by a traditional healer, history of transfusion, family history of cancer, and heterosexual origin of HIV infection. More research is needed to understand how the interactions of these risk factors with KSHV and HIV infection increase the risk of KS disease.

\section{Supplementary Material}

Refer to Web version on PubMed Central for supplementary material.

\section{Acknowledgments}

We would like to acknowledge the study staff at SOCHIMIO for their work in recruiting and enrolling participants; the IeDEA Central Africa staff and clinical officers in Cameroon for collaborating with study staff; and the staff at the Global Viral Forecasting Institute (GVFI) in Yaoundé for providing controlled climate storage space for the biological specimens. Acknowledgement is also given to Joseph Meyer, who designed and produced Figure 1 map of Cameroon ethnicities. This project has been funded in part with federal funds from the NCI, NIH under contract N01-CO-12400 and HHSN261200800001E and NIAID, NIH, under contract 1U01AI069927.

\section{References}

1. Haverkos HW. Multifactorial etiology of Kaposi's sarcoma: a hypothesis. Journal of Biosciences. 2008 Dec; 33(5):643-51. [PubMed: 19179752] 
2. Antman K, Chang Y. Kaposi's Sarcoma. New England Journal of Medicine. 2000; 342(14):102738. [PubMed: 10749966]

3. Phipps W, Ssewankambo F, Nguyen H, Saracino M, Wald A, Corey L, et al. Gender differences in clinical presentation and outcomes of epidemic Kaposi sarcoma in Uganda. PloS one. 2010 Jan. 5(11):e13936. [PubMed: 21103057]

4. Centers for Disease Control (CDC). Kaposi's Sarcoma and Pneumocystis Pneumonia Among Homosexual Men - New York City and California. Morbidity and Mortality Weekly Report (MMWR). 1981:306-8.

5. Silverberg MJ, Neuhaus J, Bower M, Gey D, Hatzakis A, Henry K, et al. Risk of cancers during interrupted antiretroviral therapy in the SMART study. AIDS (London, England). 2007 Sep 12; 21(14):1957-63.

6. Whitby D, Howard MR, Tenant-Flowers M, Brink NS, Copas A, Boshoff C, et al. Detection of Kaposi sarcoma associated herpesvirus in peripheral blood of HIV-infected individuals and progression to Kaposi's sarcoma. Lancet. 1995 Sep 23; 346(8978):799-802. [PubMed: 7674745]

7. Engels EA, Pfeiffer RM, Goedert JJ, Virgo P, McNeel TS, Scoppa SM, et al. Trends in cancer risk among people with AIDS in the United States 1980-2002. AIDS (London, England). 2006 Aug; 20(12):1645-54.

8. Chang Y, Cesarman E, Pessin MS, Lee F, Culpepper J, Knowles DM, et al. Identification of Herpesvirus-Like DNA Sequences in AIDS-Associated Kaposi's Sarcoma. Science. 1994; 266(5192):1865-9. [PubMed: 7997879]

9. Simpson GR, Schulz TF, Whitby D, Cook PM, Boshoff C, Rainbow L, et al. Prevalence of Kaposi's sarcoma associated herpesvirus infection measured by antibodies to recombinant capsid protein and latent immunofluorescence antigen. Lancet. 1996 Oct 26; 348(9035):1133-8. [PubMed: 8888167]

10. Iscovich J, Boffetta P, Franceschi S, Azizi E, Sarid R. Classic Kaposi Sarcoma: Epidemiology and Risk Factors. Cancer. 2000:8-12.

11. Bourboulia D, Whitby D, Boshoff C, Newton R, Beral V, Carrara H, et al. Serologic Evidence for Mother-to-Child Transmission of Kaposi Sarcoma-Associated Herpesvirus Infection. JAMA : the Journal of the American Medical Association. 1998 Jul 1.280(1):28. [PubMed: 9660352]

12. Marcelin A, Gorin I, Morand P, Ait-arkoub Z, Deleuze J, Morini J, et al. Quantification of Kaposi's Sarcoma-Associated Herpesvirus in Blood, Oral Mucosa, and Saliva in Patients with Kaposi’s Sarcoma. AIDS Research and Human Retroviruses. 2004; 20(7):704-8. [PubMed: 15307914]

13. Mbulaiteye SM, Goedert JJ. Human Herpesvirus 8 Seropositivity in Rural Uganda : Maturation of Sero-epidemiological Studies. Journal of Infectious Disease. 2011; 203:575-7.

14. Malope-kgokong BI, Macphail P, Mbisa G, Ratshikhopha E, Maskew M, Stein L, et al. Kaposi's Sarcoma Associated-Herpes Virus (KSHV) Seroprevalence in Pregnant Women in South Africa. Infectious Agents and Cancer. 2010; 5(14):1-8. [PubMed: 20205796]

15. Martin JN, Ganem DE, Osmond DH, Page-Shafer KA, Macrae D, Kedes DH. Sexual Transmission and the Natural History of Human Herpesvirus 8 Infection. The New England Journal of Medicine. 1998; 338:948-54. [PubMed: 9521982]

16. Gessain A, Mauclère P, van Beveren M, Plancoulaine S, Ayouba A, Essame-Oyono JL, et al. Human herpesvirus 8 primary infection occurs during childhood in Cameroon, Central Africa. International Journal of Cancer. 1999 Apr 12; 81(2):189-92.

17. Dollard SC, Butler LM, Jones AMG, Mermin JH, Chipato T, Shiboski CH, et al. Substantial Regional Difference in Human Herpesvirus 8 Seroprevalence in Sub-Saharan Africa: Insights on the Origin of the "KS Belt". International Journal of Cancer. 2010; 127(10):2395-401.

18. Ziegler JL. Endemic Kaposi's sarcoma in Africa and local volcanic soils. The Lancet. 1993 Jan 22.342:1348-51.

19. Pfeiffer RM, Wheeler WA, Mbisa G, Whitby D, Goedert JJ, de Thé G, et al. Geographic Heterogeneity of Prevalence of the Human Herpesvirus 8 in Sub-Saharan Africa: Clues About Etiology. Annals of Epidemiology. 2010 Dec; 20(12):958-63. [PubMed: 21074111]

20. Dedicoat M, Newton R. Review of the distribution of Kaposi's sarcoma-associated herpesvirus (KSHV) in Africa in relation to the incidence of Kaposi's sarcoma. British Journal of Cancer. 2003 Jan 13; 88(1):1-3. [PubMed: 12556950] 
21. Joint United Nations Programme on HIV/AIDS (UNAIDS). Global report: UNAIDS report on global AIDS epidemic 2010. 2010.

22. Mbuagbaw J, Pisoh C, Mbuagbaw L, Bengondo C, Kegoum B, Bengono G, et al. Prevalence And Characteristics Of Human Immunodeficiency Virus Associated Kaposi Sarcoma. The Internet Journal of Oncology. 2008; 5(2)

23. Rezza G, Tchangmena B, Andreoni M, Bugarini R, Toma L, Bakary DK, et al. Prevalence and Risk Factors for Human Herpesvirus Infection in Northern Cameroon. Sexually Transmitted Diseases. 2000; 27(3):159-64. [PubMed: 10726650]

24. Price AJ, Ndom P, Atenguena E, Mambou Nouemssi JP, Ryder RW. Cancer care challenges in developing countries. Cancer. 2012 Jul 15; 118(14):3627-35. [PubMed: 22223050]

25. Divaris K, Newman J, Hemingway-Foday J, Akam W, Balimba A, Dusengamungu C, et al. Adult HIV care resources, management practices and patient characteristics in the Phase 1 IeDEA Central Africa cohort. Journal of the International AIDS Society. 2012 Jan.15(2):17422. [PubMed: 23199800]

26. Mbisa GL, Miley W, Gamache CJ, Gillette WK, Esposito D, Hopkins R, et al. Detection of antibodies to Kaposi's sarcoma-associated herpesvirus: a new approach using K8.1 ELISA and a newly developed recombinant LANA ELISA. Journal of Immunological Methods. Elsevier B.V. 2010 Apr 30; 356(1-2):39-46.

27. Whitby D, Marshall VA, Bagni RK, Miley WJ, McCloud TG, Hines-Boykin R, et al. Reactivation of Kaposi's sarcoma-associated herpesvirus by natural products from Kaposi's sarcoma endemic regions. International Journal of Cancer. 2007; 120(2):321-8.

28. Wakeham K, Webb EL, Sebina I, Muhangi L, Miley W, Johnson WT, et al. Parasite infection is associated with Kaposi's sarcoma associated herpesvirus (KSHV) in Ugandan women. Infectious Agents and Cancer. BioMed Central Ltd. 2011 Jan; 6(15):1-7.

29. Ziegler J, Newton R, Bourboulia D, Casabonne D, Beral V, Mbidde E, et al. Risk factors for Kaposi's sarcoma: a case-control study of HIV-seronegative people in Uganda. International Journal of Cancer. 2003 Jan 10; 103(2):233-40.

30. Ziegler JL, Newton R, Katongole-mbidde E, Mbulataiye S, De Cock K, Wabinga H, et al. Risk factors for Kaposi's sarcoma in HIV-positive subjects in Uganda. AIDS. 1997; 11(13):1619-26. [PubMed: 9365767]

31. Nkuo-Akenji T, Ntonifor NN, Ndukum MB, Kimbi HK, Abongwa EL, Nkwescheu A, et al. Environmental factors affecting malaria parasite prevalence in rural Bolifamba, South-West Cameroon. African Journal of Health Sciencecs. 2006; 13(1):40-6.

32. Nuwaha F. Factors influencing the use of bed nets in Mbarara municipality of Uganda. The American Journal of Tropical Medicine and Hygiene. 2001 Dec; 65(6):877-82. [PubMed: 11791991]

33. Cook-Mozaffari P, Newton R, Berai V, Burkitt DP. The geographical distribution of Kaposi's sarcoma and of lymphomas in Africa before the AIDS epidemic. British Journal of Cancer. 1998; 78(11):1521-8. [PubMed: 9836488]

34. Mbulaiteye SM, Biggar RJ, Pfeiffer RM, Bakaki PM, Gamache C, Owor AM, et al. Water, Socioeconomic Factors, and Human Herpesvirus 8. Epidemiology and Social Science. 2005; 38(4):474-9.

35. Gemperli A, Sogoba N, Fondjo E, Mabaso M, Bagayoko M, Briët OJT, et al. Mapping malaria transmission in West and Central Africa. Tropical Medicine and International Health. 2006 Jul; 11(7):1032-46. [PubMed: 16827704]

36. Pelser C, Dazzi C, Graubard BI, Lauria C, Vitale F, Goedert JJ. Risk of Classic Kaposi Sarcoma with Residential Exposure to Volcanic and Related Soils in Sicily. Annals of Epidemiology. Elsevier Inc. 2009 Aug; 19(8):597-601.

37. Davis DA, Rinderknecht AS, Zoeteweij JP, Aoki Y, Read-Connole EL, Tosato G, et al. Hypoxia induces lytic replication of Kaposi sarcoma-associated herpesvirus. Blood. 2001 May 15; 97(10): 3244-50. [PubMed: 11342455]

38. Reece JJ, Siracusa MC, Southard TL, Brayton CF, Urban JF, Scott AL. Hookworm-induced Persistent Changes to the Immunological Environment of the Lung. Infection and Immunity. 2008 Aug; 76(8):3511-24. [PubMed: 18505812] 
39. Asito AS, Moormann AM, Kiprotich C, Ng'ang'a ZW, Ploutz-Snyder R, Rochford R. Alterations on peripheral B cell subsets following an acute uncomplicated clinical malaria infection in children. Malaria Journal. 2008 Jan.7:238. [PubMed: 19019204]

40. Ziegler JL, Simonart T, Snoeck R. Kaposi's sarcoma, oncogenic viruses, and iron. Journal of Clinical Virology. 2001; 20:127-30. [PubMed: 11166660]

41. Gray RH, Wawer MJ. Probability of Heterosexual HIV-1 Transmission per Coital Act in SubSaharan Africa. Journal of Infectious Disease. 2012 Feb 1; 205(3):351-2.

42. De Sanjose S, Mbisa G, Perez-Alvarez S, Benavente Y, Sukvirach S, Hieu NT, et al. Geographic variation in the prevalence of Kaposi sarcoma-associated herpesvirus and risk factors for transmission. The Journal of Infectious Diseases. 2009 May 15; 199(10):1449-56. [PubMed: 19351262] 


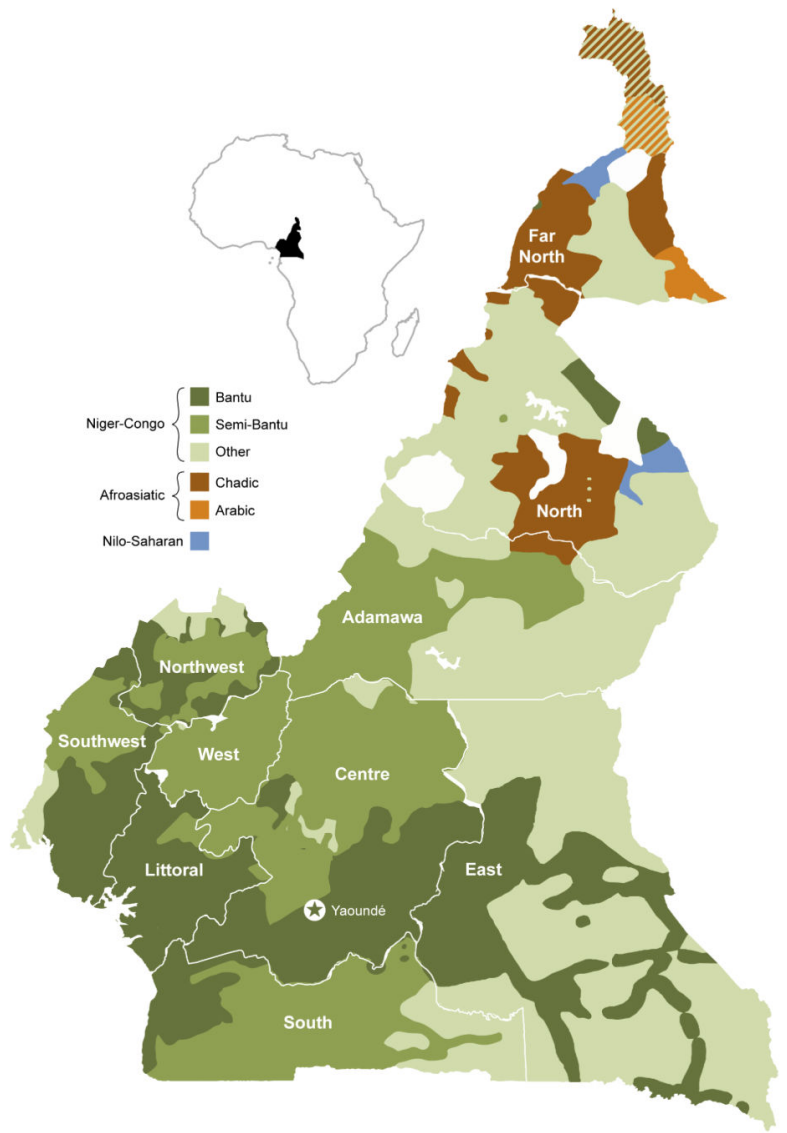

Figure 1.

Map of Cameroon showing the country's administrative subdivisions (regions) and a broad ethnic classification of its population, according to ISO 639-3 standard designations.

(www.ethnologue.com) 
Table 1

Descriptive characteristics of HIV-positive and HIV-negative KS cases and controls

\begin{tabular}{|c|c|c|c|c|}
\hline & \multicolumn{2}{|c|}{ KS Cases } & \multicolumn{2}{|c|}{ KS Controls } \\
\hline & $\begin{array}{l}\text { HIV-positive } \\
\quad \text { N }(\%)\end{array}$ & $\begin{array}{l}\text { HIV-negative } \\
\text { N (\%) }\end{array}$ & $\begin{array}{l}\text { HIV-positive } \\
\quad \text { N }(\%)\end{array}$ & $\begin{array}{l}\text { HIV-negative } \\
\text { N }(\%)\end{array}$ \\
\hline Total N & 161 & 14 & 680 & 322 \\
\hline \multicolumn{5}{|l|}{ KSHV seropositivity } \\
\hline K8.1 positive & $154(95.7)$ & $14(100.0)$ & $527(77.5)$ & $241(74.8)$ \\
\hline Orf 73 positive & $145(90.1)$ & $14(100.0)$ & $486(71.5)$ & $214(66.5)$ \\
\hline Overall positive & $158(98.1)$ & $14(100.0)$ & $550(80.9)$ & $257(79.8)$ \\
\hline Proportion Male & $91(56.5)$ & $14(100.0)$ & 407 (59.9) & $188(58.4)$ \\
\hline \multicolumn{5}{|l|}{ Age range in years } \\
\hline $19-29$ & $21(13.0)$ & $2(14.3)$ & $83(12.2)$ & $43(13.4)$ \\
\hline $30-39$ & $67(41.6)$ & $1(7.1)$ & $276(40.6)$ & $139(43.2)$ \\
\hline $40-49$ & $45(28.0)$ & $3(21.4)$ & $190(27.9)$ & $82(25.5)$ \\
\hline 250 & $28(17.4)$ & $8(57.1)$ & $131(19.3)$ & $58(18.0)$ \\
\hline \multicolumn{5}{|l|}{ Occupation } \\
\hline Professional & $52(32.5)$ & $6(42.9)$ & $232(34.2)$ & $158(49.1)$ \\
\hline Semi-skilled & $21(13.1)$ & $0(0.0)$ & $101(14.9)$ & $33(10.2)$ \\
\hline Trader/sales & $29(18.1)$ & $1(7.1)$ & $172(25.4)$ & $48(14.9)$ \\
\hline Farmer & $13(8.1)$ & $4(28.6)$ & $34(5.0)$ & $10(3.1)$ \\
\hline Unemployed & $45(28.1)$ & $3(21.4)$ & $139(20.5)$ & $73(22.7)$ \\
\hline \multicolumn{5}{|l|}{ Marital status } \\
\hline Single/Divorced/Widowed & $77(47.8)$ & $4(28.6)$ & $272(40.0)$ & $115(35.7)$ \\
\hline Married & $70(43.5)$ & $9(64.3)$ & $319(46.9)$ & $170(52.8)$ \\
\hline Open relationship & $14(8.7)$ & $1(7.1)$ & $89(13.1)$ & $37(11.5)$ \\
\hline \multicolumn{5}{|l|}{ Educational Attainment } \\
\hline None/primary & $34(21.1)$ & $4(28.6)$ & $155(22.8)$ & $54(16.8)$ \\
\hline Secondary & $96(59.6)$ & $6(42.9)$ & $363(53.5)$ & $192(59.6)$ \\
\hline Higher & $31(19.3)$ & $4(28.6)$ & $161(23.7)$ & $76(23.6)$ \\
\hline \multicolumn{5}{|l|}{ Region of origin } \\
\hline Littoral & $9(5.7)$ & $1(7.1)$ & $32(4.8)$ & $30(9.4)$ \\
\hline South (South, Center, East) & $98(62.4)$ & $8(57.1)$ & $358(53.5)$ & $126(39.4)$ \\
\hline West (West, NW, SW) & $45(28.7)$ & $5(35.7)$ & $253(37.8)$ & $141(44.1)$ \\
\hline North (North, Adamawa, Extreme North) & $5(3.2)$ & $0(0.0)$ & $26(3.9)$ & $23(7.2)$ \\
\hline \multicolumn{5}{|l|}{ Ethnic group } \\
\hline Bantu & $108(67.1)$ & $9(64.3)$ & $395(58.1)$ & $161(50.0)$ \\
\hline Semi-bantu & $45(28.0)$ & $5(35.7)$ & $255(37.5)$ & $139(43.2)$ \\
\hline Other & $8(5.0)$ & $0(0.0)$ & $30(4.4)$ & $22(6.8)$ \\
\hline
\end{tabular}

$\mathrm{KS}=$ Kaposi's Sarcoma 
HIV = Human Immunodeficiency Virus

$\mathrm{N}=$ Number

KSHV $=$ Kaposi's Sarcoma Herpesvirus

Overall positive $=$ Defined as having a positive test to either or both K8.1 and Orf73 ELISA tests. 


\section{Table 2}

Unadjusted odds ratios (OR) and 95\% confidence intervals (CI) of KS risk factors among HIV-positive cases and HIV-positive controls, stratified by selected demographic, socioeconomic and environmental factors.

\begin{tabular}{|c|c|c|c|}
\hline & $\begin{array}{c}\text { Cases HIV-positive } \\
\text { N }(\%)\end{array}$ & $\begin{array}{c}\text { Controls HIV-positive } \\
\text { N (\%) }\end{array}$ & $\begin{array}{c}\text { Univariate } \\
\text { OR }(95 \% \text { CI })\end{array}$ \\
\hline Total N & 161 & 680 & \\
\hline \multicolumn{4}{|l|}{$\mathrm{KSHV}$ serostatus ${ }^{a}$} \\
\hline K8.1 positive & $154(95.7)$ & $527(77.5)$ & $6.3(2.9,13.7)^{*}$ \\
\hline Orf 73 positive & $145(90.1)$ & $486(71.5)$ & $3.6(2.1,6.2)^{*}$ \\
\hline Overall positive & $158(98.1)$ & $550(80.9)$ & $12.3(3.9,39.0) *$ \\
\hline \multicolumn{4}{|l|}{ Occupation } \\
\hline Professional & $52(32.5 \%)$ & $232(34.2 \%)$ & $0.7(0.4,1.2)$ \\
\hline Semi-skilled & $21(13.1 \%)$ & $101(14.9 \%)$ & $0.7(0.4,1.3)$ \\
\hline Trader/sales & $29(18.1 \%)$ & $172(25.4 \%)$ & $0.5(0.3,0.9)^{*}$ \\
\hline Farmer & $13(8.1 \%)$ & $34(5 \%)$ & $1.2(0.6,2.6)$ \\
\hline Unemployed & $45(28.1 \%)$ & $139(20.5 \%)$ & 1.0 \\
\hline \multicolumn{4}{|l|}{ Marital status } \\
\hline Single/Divorced/Widowed & $77(47.8 \%)$ & $272(40 \%)$ & $1.3(0.8,1.9)$ \\
\hline Married & $70(43.5 \%)$ & $319(46.9 \%)$ & 1.0 \\
\hline Open relationship & $14(8.7 \%)$ & $89(13.1 \%)$ & $0.7(0.4,1.3)$ \\
\hline \multicolumn{4}{|l|}{ Education attainment } \\
\hline None/primary & $34(21.1 \%)$ & $155(22.8 \%)$ & $1.1(0.64,1.93)$ \\
\hline Secondary & $96(59.6 \%)$ & $363(53.5 \%)$ & $1.4(0.86,2.12)$ \\
\hline Higher & $31(19.3 \%)$ & $161(23.7 \%)$ & 1.0 \\
\hline \multicolumn{4}{|l|}{ House has electricity } \\
\hline Yes & $146(90.7)$ & $646(95.0)$ & 1.0 \\
\hline No & $15(9.3)$ & $34(5.0)$ & $1.9(1.01,3.6)^{*}$ \\
\hline \multicolumn{4}{|l|}{ Participant sleeps under a mosquito net } \\
\hline Yes & $64(40.0)$ & $344(50.6)$ & 1.0 \\
\hline No & $96(60.0)$ & $336(49.4)$ & $1.5(1.1,2.2)^{*}$ \\
\hline \multicolumn{4}{|l|}{ Region of origin } \\
\hline Littoral & $9(5.7)$ & $32(4.8)$ & $1.6(0.7,3.5)$ \\
\hline South (South, Center, East) & $98(62.4)$ & $359(53.5)$ & $1.5(1.0,2.3)^{*}$ \\
\hline West (West, NW, SW) & $45(28.7)$ & $253(37.8)$ & 1.0 \\
\hline North (North, Adamawa, Extreme North) & $5(3.2)$ & $26(3.9)$ & $1.1(0.4,3.1)$ \\
\hline \multicolumn{4}{|l|}{ Ethnic group } \\
\hline Bantu & $108(67.1)$ & $395(58.1)$ & $1.5(1.1,2.3)^{*}$ \\
\hline Semi-bantu & $45(28.0)$ & $255(37.5)$ & 1.0 \\
\hline Other & $8(5.0)$ & $30(4.4)$ & $1.6(0.7,3.6)$ \\
\hline
\end{tabular}




\begin{tabular}{|c|c|c|c|}
\hline & $\begin{array}{c}\text { Cases HIV-positive } \\
\text { N }(\%)\end{array}$ & $\begin{array}{c}\text { Controls HIV-positive } \\
\text { N (\%) }\end{array}$ & $\begin{array}{c}\text { Univariate } \\
\text { OR }(95 \% \text { CI })\end{array}$ \\
\hline \multicolumn{4}{|l|}{ History of tobacco use } \\
\hline Yes & $50(31.1)$ & $167(24.6)$ & $1.6(1.1,2.5)^{*}$ \\
\hline No & $111(68.9)$ & $512(75.4)$ & 1.0 \\
\hline History of alcohol use & 161 & 680 & \\
\hline Yes & $128(79.5)$ & $479(70.4)$ & $1.8(1.2,2.8)^{*}$ \\
\hline No & $33(20.5)$ & $201(29.6)$ & 1.0 \\
\hline \multicolumn{4}{|l|}{ Color of soil where spent time as a child } \\
\hline Black & $30(18.9)$ & $106(15.8)$ & $1.2(0.8,1.9)$ \\
\hline Brown & $17(10.7)$ & $94(14.0)$ & $0.8(0.4,1.4)$ \\
\hline Red & $103(64.8)$ & $437(64.9)$ & 1.0 \\
\hline White & $9(5.7)$ & $36(5.3)$ & $1.1(0.5,2.3)$ \\
\hline \multicolumn{4}{|l|}{ As a child, how often did you play outside barefoot } \\
\hline Ever (Always/Most of the time/Often/Rarely) & $153(96.8)$ & $637(95.1)$ & $1.6(0.6,4.2)$ \\
\hline Never & $5(3.2)$ & $33(4.9)$ & 1.0 \\
\hline \multicolumn{4}{|l|}{ Source of water - bathing } \\
\hline Private source & $58(36.0)$ & $219(32.2)$ & 1.0 \\
\hline Communal source & $86(53.4)$ & $386(56.8)$ & $0.8(0.6,1.2)$ \\
\hline Surface water source & $17(10.6)$ & $75(11.0)$ & $0.8(0.4,1.4)$ \\
\hline \multicolumn{4}{|l|}{ No. of regular sexual partners (lifetime) } \\
\hline $0-1$ & $49(32.0)$ & $201(31.4)$ & 1.0 \\
\hline $2-3$ & $36(23.5)$ & $214(33.4)$ & $0.7(0.4,1.1)$ \\
\hline $4+$ & $68(44.4)$ & $226(35.3)$ & $1.3(0.8,1.9)$ \\
\hline \multicolumn{4}{|l|}{ History of condom use } \\
\hline Never & $18(15.0)$ & $61(11.4)$ & $2.0(1.0,4.0)^{*}$ \\
\hline Sometimes & $53(44.2)$ & $191(35.8)$ & $2.0(1.2,3.4)^{*}$ \\
\hline Most of the time & $22(18.3)$ & $80(15.0)$ & $2.0(1.1,3.8)^{*}$ \\
\hline Always & $27(22.5)$ & $201(37.7)$ & 1.0 \\
\hline \multicolumn{4}{|l|}{ History of an STI } \\
\hline Yes & $108(68.4)$ & $288(57.8)$ & $1.7(1.1,2.4)^{*}$ \\
\hline No & $50(31.6)$ & $283(42.2)$ & 1.0 \\
\hline \multicolumn{4}{|l|}{ Received treatment from a traditional healer } \\
\hline Yes & $106(65.8)$ & $304(44.7)$ & $2.4(1.7,3.5)^{*}$ \\
\hline No & $55(34.2)$ & $376(55.3)$ & 1.0 \\
\hline \multicolumn{4}{|l|}{ History of transfusion } \\
\hline Yes & $46(28.9)$ & $120(17.8)$ & $1.9(1.3,2.8)^{*}$ \\
\hline No & $113(71.1)$ & $556(82.2)$ & 1.0 \\
\hline Family history of cancer & & & \\
\hline
\end{tabular}




\begin{tabular}{|l|c|c|c|}
\hline & $\begin{array}{c}\text { Cases HIV-positive } \\
\mathbf{N}(\boldsymbol{\%})\end{array}$ & $\begin{array}{c}\text { Controls HIV-positive } \\
\mathbf{N}(\boldsymbol{\%})\end{array}$ & $\begin{array}{c}\text { Univariate } \\
\text { OR (95\% CI) }\end{array}$ \\
\hline Yes & $37(24.8)$ & $101(15.3)$ & $1.8(1.2,2.7)^{*}$ \\
\hline No & $112(75.2)$ & $560(84.7)$ & 1.0 \\
\hline Origin of HIV exposure & & & \\
\hline Heterosexual sex & $87(54.0)$ & $266(39.3)$ & $1.9(1.3,2.7)^{*}$ \\
\hline Other/Unknown & $74(46.0)$ & $410(60.7)$ & 1.0 \\
\hline History of ART & & & \\
\hline Yes & $88(84.6)$ & $457(84.5)$ & $0.9(0.5,1.7)$ \\
\hline No & $16(15.4)$ & $84(15.5)$ & 1.0 \\
\hline HIV Clinical Stage at the start of ART & & & \\
\hline I-II & $10(28.6)$ & $96(61.5)$ & 1.0 \\
\hline III-IV & $25(71.4)$ & $60(38.5)$ & $3.8(1.7,8.6)^{*}$ \\
\hline Duration of ART & & & \\
\hline$<6.5$ months & $39(44.3)$ & $69(15.3)$ & $5(2.9,8.6)^{*}$ \\
\hline $6.5-18$ months & $16(18.2)$ & $80(17.8)$ & $2.0(1.0,3.9)^{*}$ \\
\hline >18 months & $33(37.5)$ & $301(66.9)$ & 1.0 \\
\hline
\end{tabular}

p $<0.05$

${ }^{a}$ Referent group for KSHV serostatus is KSHV seronegative.

KS = Kaposi's Sarcoma

$\mathrm{N}=$ number

KSHV = Kaposi's Sarcoma Herpesvirus

Overall positive $=$ Defined as having a positive test to either or both K8.1 and Orf73 ELISA tests.

STI $=$ Sexually Transmitted Infection

HIV = Human Immunodeficiency Virus

ART $=$ Anti-retroviral Therapy 
Table 3

Multivariate odds ratios (OR) and 95\% confidence intervals (CI) of KS risk factors among HIV-seropositive cases and HIV-seropostive controls, stratified by selected demographic, socioeconomic and environmental factors.

\begin{tabular}{|c|c|c|c|}
\hline & $\begin{array}{c}\text { Cases HIV-positive } \\
\text { N }(\%)\end{array}$ & $\begin{array}{c}\text { Controls HIV-positive } \\
\text { N }(\%)\end{array}$ & $\begin{array}{l}\text { Multivariate } \\
\text { OR }(95 \% \text { CI })\end{array}$ \\
\hline Total $\mathbf{N}$ & 161 & 680 & \\
\hline \multicolumn{4}{|l|}{$\mathrm{KSHV}$ serostatus ${ }^{a}$} \\
\hline K8.1 positive & $154(95.7)$ & $527(77.5)$ & $--^{1}$ \\
\hline Orf 73 positive & $145(90.1)$ & $486(71.5)$ & --- \\
\hline Overall positive $^{b}$ & $158(98.1)$ & $550(80.9)$ & $9.6(2.9,31.5)^{*}$ \\
\hline \multicolumn{4}{|l|}{ House has electricity } \\
\hline Yes & $146(90.7)$ & $646(95.0)$ & 1.0 \\
\hline No & $15(9.3)$ & $34(5.0)$ & $1.9(0.9,4.5)$ \\
\hline \multicolumn{4}{|l|}{ Participant sleeps under a mosquito net } \\
\hline Yes & $64(40.0)$ & $344(50.6)$ & 1.0 \\
\hline No & $96(60.0)$ & $336(49.4)$ & $1.9(1.2,2.9)^{*}$ \\
\hline Region of origin ${ }^{c}$ & & & --- \\
\hline \multicolumn{4}{|l|}{ Ethnic group } \\
\hline Bantu & $108(67.1)$ & $395(58.1)$ & $1.5(0.9,2.4)$ \\
\hline Semi-bantu & $45(28.0)$ & $255(37.5)$ & 1.0 \\
\hline Other & $8(5.0)$ & $30(4.4)$ & $3.1(1.1,9.3)^{*}$ \\
\hline \multicolumn{4}{|l|}{ History of tobacco use } \\
\hline Yes & $50(31.1)$ & $167(24.6)$ & $1.1(0.7,1.9)$ \\
\hline No & $111(68.9)$ & $512(75.4)$ & 1.0 \\
\hline History of alcohol use & 161 & 680 & \\
\hline Yes & $128(79.5)$ & $479(70.4)$ & $1.4(0.8,2.5)$ \\
\hline No & $33(20.5)$ & $201(29.6)$ & 1.0 \\
\hline \multicolumn{4}{|l|}{ Color of soil where spent time as a child } \\
\hline Black & $30(18.9)$ & $106(15.8)$ & $1.5(0.8,2.7)$ \\
\hline Brown & $17(10.7)$ & $94(14.0)$ & $0.8(0.4,1.6)$ \\
\hline Red & $103(64.8)$ & 437 (64.9) & 1.0 \\
\hline White & $9(5.7)$ & $36(5.3)$ & $1.1(.5,2.5)$ \\
\hline \multicolumn{4}{|l|}{ As a child, how often did you play outside barefoot } \\
\hline Ever (Always/Most of the time/Often/Rarely) & $153(96.8)$ & $637(95.1)$ & $2.8(0.8,10.4)$ \\
\hline Never & $5(3.2)$ & $33(4.9)$ & 1.0 \\
\hline \multicolumn{4}{|l|}{ Source of water - bathing } \\
\hline Private source & $58(36.0)$ & $219(32.2)$ & 1.0 \\
\hline Communal source & $86(53.4)$ & $386(56.8)$ & $0.9(0.6,1.5)$ \\
\hline
\end{tabular}




\begin{tabular}{|c|c|c|c|}
\hline & $\begin{array}{c}\text { Cases HIV-positive } \\
\text { N }(\%)\end{array}$ & $\begin{array}{c}\text { Controls HIV-positive } \\
\text { N (\%) }\end{array}$ & $\begin{array}{l}\text { Multivariate } \\
\text { OR }(95 \% \text { CI })\end{array}$ \\
\hline Surface water source & $17(10.6)$ & $75(11.0)$ & $0.7(0.3,1.4)$ \\
\hline \multicolumn{4}{|l|}{ No. of regular sexual partners (lifetime) } \\
\hline $0-1$ & $49(32.0)$ & $201(31.4)$ & 1.0 \\
\hline $2-3$ & $36(23.5)$ & $214(33.4)$ & $0.8(0.4,1.4)$ \\
\hline $4+$ & $68(44.4)$ & $226(35.3)$ & $1.1(0.7,1.9)$ \\
\hline History of condom use ${ }^{d}$ & & & --- \\
\hline \multicolumn{4}{|l|}{ History of an STI } \\
\hline Yes & $108(68.4)$ & $288(57.8)$ & $1.2(.8,1.9)$ \\
\hline No & $50(31.6)$ & $283(42.2)$ & 1.0 \\
\hline \multicolumn{4}{|l|}{ Received treatment from a traditional healer } \\
\hline Yes & $106(65.8)$ & $304(44.7)$ & $2.3(1.5,3.7)^{*}$ \\
\hline No & $55(34.2)$ & $376(55.3)$ & 1.0 \\
\hline \multicolumn{4}{|l|}{ History of transfusion } \\
\hline Yes & $46(28.9)$ & $120(17.8)$ & $2.4(1.5,3.9)^{*}$ \\
\hline No & $113(71.1)$ & $556(82.2)$ & 1.0 \\
\hline \multicolumn{4}{|l|}{ Family history of cancer } \\
\hline Yes & $37(24.8)$ & $101(15.3)$ & $1.9(1.1,3.1)^{*}$ \\
\hline No & $112(75.2)$ & $560(84.7)$ & 1.0 \\
\hline \multicolumn{4}{|l|}{ Origin of HIV exposure } \\
\hline Heterosexual sex & $87(54.0)$ & $266(39.3)$ & $1.5(1.0,2.4)^{*}$ \\
\hline Other/Unknown & $74(46.0)$ & $410(60.7)$ & 1.0 \\
\hline History of $\mathrm{ART}^{e}$ & & & --- \\
\hline HIV Clinical Stage at the start of $\mathrm{ART}^{e}$ & & & --- \\
\hline Duration of $\mathrm{ART}^{e}$ & & & --- \\
\hline
\end{tabular}

* $\mathrm{p}<.05$

${ }^{a}$ Referent group for KSHV serostatus is KSHV seronegative.

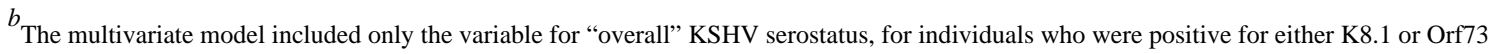
antigens.

${ }^{c}$ Region of origin was not included in multivariate model because highly correlated with ethnic group.

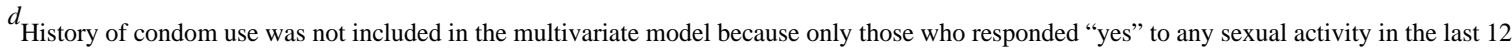
months answered the question about frequency of condom use.

${ }^{e}$ History of ART, HIV Clinical Stage at the start of ART, and duration of ART, were not included in the multivariate model due to unavailability of ART information for many participants.

KS = Kaposi's Sarcoma

$\mathrm{N}=$ number

KSHV = Kaposi's Sarcoma Herpesvirus

Overall positive $=$ Defined as having a positive test to either or both K8.1 and Orf73 ELISA tests. 
STI $=$ Sexually Transmitted Infection

HIV = Human Immunodeficiency Virus

ART $=$ Anti-retroviral Therapy 